\title{
Property Rights in UK Uplands and the Implications for Policy and Management
}

\author{
Quinn, C.H., Reed, M.S. \& Hubacek, K.
}

\begin{abstract}
Understanding the property rights regimes that govern resource management in uplands is key to developing environmental policy that supports sustainable rural livelihoods and encourages the delivery of important ecosystem services in the face of change. The UK uplands are important for the range of ecosystem services they provide, from biodiversity, recreation and carbon storage, to the provision of food, fibre and water, as well as flood prevention. Upland environments are subject to a complicated system of property rights regimes. While land might be in private ownership, rights of withdrawal, access and management of different resources on that land may be afforded to different stakeholders. In many areas this can result in private property regimes, common property regimes and state control overlapping as they seek to manage resources in the same landscape for different objectives, sometimes leading to conflict between the different rights holders. At the same time climate change, economic development and changes to agricultural and other policy drivers means that the relative importance of different ecosystems services is changing along with the balance of power between different stakeholders.
\end{abstract}

This research explores the property regimes in three upland areas: the Peak District National Park, the Nidderdale Area of Outstanding Natural Beauty and the uplands of Dumphries and Galloway. Using data from a range of qualitative and quantitative interviews and participant observation this paper examines the extent to which the current property regimes lead to conflict, influence decisions about land management for different ecosystem services, and act as a barrier to sustainable management. Recommendations are made for national policy, and the wider implications are explored for future environmental policy development under complex tenure regimes.

Keywords: Moorlands, ecosystem services, sustainable management

\section{Introduction}

Uplands are significant in the UK because of their national and international importance as areas dominated by moorland habitats that support globally rare species (Holden et al. 2007). The UK alone has $75 \%$ of the worlds heather moorland and $15 \%$ of the worlds blanket peat in its upland areas (Tallis et al. 1998). Both these habitats are recognised as key for biodiversity and have a range of conservation designations from Sites of Special Scientific Interest (SSSI) to Special Protection Areas (SPA) (Dougill et al. 2006). In addition to biodiversity, uplands are also an important source of many other ecosystem services. More than $70 \%$ of water supplies in the UK come from upland catchments (Heal 2003) making them crucial for social and economic activities in lowland rural and urban areas. They are also important for their role in water storage 
to prevent flooding downstream. Peat soils in uplands represent the UK's largest store of carbon, with over 20 times more carbon stored than in the all the UK forests. It has been estimated that as much as 400,000 more tonnes of carbon could be stored in peat soils every year with good management (Moors for the Future 2007) The importance of recreation and the tourism industry cannot be underestimated either (Reed et al. In press). The Peak District National Park alone receives 22 million day visitors a year and uplands are widely valued by walkers and climbers for the tranquillity and open landscapes they provide (Suckall et al. In Press).

Although often considered wilderness, the uplands in the UK have a long history of management for the production of food and fibre. Woodland clearance and livestock grazing in the uplands can be traced back to the Neolithic, over 2000 years ago (Bevan In press). This clearance, in combination with climate change, led to the spread of heather moorland and blanket peat (Simmons 2004). Up until the $18^{\text {th }}$ century moorlands were mostly unenclosed commons, part of the royal estates, and local tenants had rights to graze livestock, cut peat, quarry stone and collect plants and other natural materials (Bevan In press). However, the enclosures of the $18^{\text {th }}$ century saw the widespread removal of common rights and land taken into private property (lbid). The view at the time was that commons systems were backward and only private land could be efficiently and effectively managed. There was also a drive to enclose moorlands into shooting estates. However, enclosure was not universal and some moors still retain common grazing rights.

Currently upland land management is predominantly for sheep farming or game shooting. In England over $50 \%$ of moorlands are managed for grouse (Sotherton et al. In press). Private landowners or shooting tenants employ gamekeepers to manage habitats and control predators (Ibid). The key habitat management tool is rotational burning of heather to provide a mosaic of different age heather stands so as to maximise territories for grouse (Watson \& Miller 1976). Upland sheep farming also uses the same moorland areas that are managed for grouse. Upland farming has a history being subsidised by government, through the European Common Agricultural Policy (CAP). CAP was first established to secure a fair standard of living for farmers and secure food supplies at affordable prices. It ran into problems almost immediately because guaranteed prices led to overproduction and surpluses. The Peak District alone saw a 275\% increase in sheep numbers between 1950 and 1976 (Gardner et al. In press). To address the imbalance quotas and set aside were introduced but it wasn't until the 1990's that price support was removed. Most recently reform has removed production based subsidies altogether and replaced them with area based payments and agri-environment schemes (Ibid). Upland stocking rates have fallen by $8 \%$ in the period between 2004-2006, suggesting that the new reforms are starting to have the desired effect (Ibid).

There are now pressures for upland land management to deliver on other services, such as biodiversity, water, carbon and space for recreation. However, it is not clear whether current management for production of sheep and game can do this. For example, water discolouration in upland waters, caused by dissolved organic carbon, 
has shown as much as a $65 \%$ increase over the last 12 years (Worral et al. 2006). This loss of carbon has potentially huge implications for water quality and the carbon storage capabilities of moorlands. But it is unclear at this stage how much of this carbon loss is due to land management and particularly rotational burning (Holden et al. 2007). At the same time the use of uplands for recreation can bring the public into conflict with farmers and gamekeepers when walkers (and especially those with dogs) disturb sheep during lambing or grouse during the nesting season (Curry In press).

The demand for other services from the uplands has led to new policy at national, European and international levels (Reed et al. In press). Change in agricultural policy and wide ranging environmental regulations reflect the desire to improve biodiversity conservation. In addition, the UK's obligations under the Kyoto protocol and the EU Water framework Directive have shifted the balance in priorities for upland areas towards water and carbon services and significant changes in land management may be necessary to meet these obligations (Lane 2003). In 2005 the Countryside and Rights of Way Act (CROW) 2000 was implemented in England and Wales. It allows open access for the public on foot to mountains, moorland, downland, and heathland and to common land, again with potentially significant impacts for management. At the same time demographic and climate changes mean that it is uncertain what the impact of all these policy changes will be in the longer term (Reed et al. In press). These new and sometimes competing demands also mean that there are now many more individuals, organisations and government departments who have a stake, and in some cases as say, in how uplands are managed.

This paper looks at the role and distribution of property rights between stakeholders in the UK uplands and how these property rights affect the sustainable management of upland areas. A property right is the 'authority to undertake particular actions related to a specific domain' (Commons 1968 in Schlager \& Ostrom 1992). Schlager and Ostrom identify five property rights as important in natural resource management (1992). These are:

Access

Withdrawal

Management

Exclusion

Alienation
Non subtractive use (e.g. access to a national park)

The right to take resource units (e.g. fishing permits) where resource units most often become private property on capture The right to make decisions and improvements in resource allocation

The right to make decisions on who can access the resource or withdraw resource units

The ability to sell or transfer rights

They attribute these rights in bundles to a set of generic property rights holders, from an authorised entrant who would only have rights of access through to an owner who would hold the full bundle of rights up to and including the right to sell or transfer withdrawal, management and exclusion rights (see table 1) (1992). 
Table 1: bundles of rights (vertical axis) associated with different property rights holders (horizontal axis) (from Schlager and Ostrom, 1992)

\begin{tabular}{|l|l|l|l|l|l|}
\hline & Owner & Proprietor & Claimant & $\begin{array}{l}\text { Authorized } \\
\text { User }\end{array}$ & $\begin{array}{l}\text { Authorized } \\
\text { Entrant }\end{array}$ \\
\hline Access & X & X & X & X & X \\
\hline Withdrawal & X & X & X & X & \\
\hline Management & X & X & X & & \\
\hline Exclusion & X & X & & & \\
\hline Alienation & X & & & & \\
\hline
\end{tabular}

By examining how these property rights are distributed between stakeholders in uplands this paper aims to examine the extent to which the current property regimes lead to conflict, influence decisions about land management for different ecosystem services, and act as a barrier to sustainable management.

\section{Study areas}

Established in 1951, the Peak District National Park was the UK's first National Park. It is situated at the southern end of the Pennine Hills, straddling four Government regions (East Midlands, West Midlands, North West, Yorkshire and Humber) that together contain around $48 \%$ of England's population, making it one of the world's most visited national parks with over 22 million visitors a year (Peak District National Park 2004).

In addition to the demands that these visitors put on the landscape, the area has a resident human population of 38,000 (Office for National Statistics 2003). As with many other UK uplands, the Peak District has undergone significant demographic changes. Many new residents have moved to the Park to retire or to purchase holiday homes while younger, unskilled workers have been priced out of local housing markets. Both farming and grouse-shooting activities operate at the margins of financial viability, and are reliant on agricultural subsidies. Some $93 \%$ of the Park qualifies for funding under the European Commission Directive for special assistance to Less Favoured Areas (75/268).

In 1994 Nidderdale was designated an Area of Outstanding Natural Beauty (AONB). The primary aim of an AONB is to 'conserve and enhance the natural beauty of the landscape' (National Association for AONBs 2003). The Nidderdale AONB covers 233 square miles $\left(603 \mathrm{~km}^{2}\right)$ on the eastern boundary of the Yorkshire Dales National Park (Nidderdale AONB 2008). Approximately 15,000 people live and work within the Nidderdale AONB. The economy is dominated by agriculture and tourism with the majority of land in private ownership.

The third area under study is focused in and around the Galloway Forest Park in Dumfries and Galloway, a council area in South West Scotland. This area differs from the previous study sites in that the predominant land uses are forestry and sheep farming with very few moors managed or shot for grouse. The Forest Park is owned by the state and managed for timber, biodiversity and recreation by the Forestry 
Commission for Scotland (Forestry Commission Scotland 2008). Outside of the Forest Park land is privately owned and managed predominantly for timber, with some areas for sheep farming. In the past prices for UK timber have been low, but more recently the demand for wood for biofuels and timber from sustainable sources has seen prices increase.

\section{Research Design}

This study on property rights is part of a larger study examining the sustainability of UK uplands (for more information see http://www.env.leeds.ac.uk/sustainableuplands). The larger study identified a range of different stakeholders, using stakeholder analysis, who have rights and responsibilities in uplands (Prell et al. In press). During focus groups and interviews in each of the study areas participants were asked to identify and categorise stakeholders (Ibid). From the 200 plus organisations that were identified as having a stake in upland management a total of eight categories were created by the stakeholders during follow up interviews and focus groups. For this study data collected through semi-structured interviews in each of the study sites, questionnaires and focus groups in the Peak District and Nidderdale, and non-participant observation in Nidderdale, were analysed using Grounded Theory Analysis (Corbin \& Strauss 1990) to reveal the current distribution of property rights in uplands between the eight stakeholder categories, to identify the role of property rights in conflicts between stakeholders, and whether property rights support or hinder decision making regarding land management.

\section{Distribution of property rights in upland management regimes}

The current distribution of property rights between the eight stakeholder categories is summarised in Table 2. Recreation and tourism groups, representing the general public, have rights of access to moorlands in upland areas in England as set out in the CROW Act. This legislation was the result of a long campaign for rights to access the countryside that dates back to the 1800s (Bevan In press). Prior to the CROW Act public access to the moorlands was restricted to a few paths and public rights of way. In Scotland rights of access are set out in the Land Reform (Scotland) Act. Legislation not only gives the public rights of access but also places some management rights in the hands of statutory bodies such as Natural England. SSSI designation and the requirement for moorland management plans mean that a lot of upland management is influenced by and must be approved by statutory bodies.

Conservation organisations only have property rights over land which they own. Organisations such as the Wildlife Trusts own and manage nature reserves across the country specifically for conservation. However, they do not have any rights over land outside their ownership. For these areas they campaign and lobby government to increase environmental protection through improved legislation. Water companies also only have wide ranging property rights over land which they own. However, water companies also have rights to withdraw water from upland catchments, many of which are in the hands of private owners. Although government regulation of farming 
practices such as herbicide and pesticide use, and government obligations under the Water Framework Directive seek to improve and protect water quality the water companies themselves are unable to dictate land management on private land in their water catchments.

Forestry in uplands can either be in private ownership or owned by the state and managed by the forestry commission. In Dumfries and Galloway forestry is the dominant land use and is distributed equally between state and private property. In Nidderdale and the Peak District sheep farming and grouse moors are the dominant land use. Farmers can either own the land that they manage, giving them a large bundle of rights from access to alienation, or they can be tenant farmers where their rights are set out in tenancy agreements. In the Peak District farming tenancies are such that in general one farmer has access to one area of moorland for grazing and sheep from other farmers are excluded. Land management is generally the responsibility of the land owner and the numbers of sheep allowed to graze the moorland are set out in the tenancy agreements.

In Nidderdale however many of the moorlands are grazed communally by gateholders. Gateholders are groups of tenant farmers whose tenancies allow them to graze particular moorlands. Each 'gate' represents one sheep and so the number of gates held by a farmer dictates the number of sheep that he can graze. The total number of gates on a moor is generally historical, with some moorlands being able to trace the use of the gated system back to the 1800s. Gated moorlands are owned by private landowners and in general also managed as grouse moors. Moorland owners are able to control the number of sheep grazed by the use of gates but also by holding gates in hand'. This means that some gates are not attached to a tenancy and so reduce the total number of sheep that are grazed. Landowners have been able to do this because the number of farmers has reduced over the years and tenancies have been merged. Where this has happened not all gates have been passed onto the new tenant. On some moors gateholder meetings are still held to determine the dates for gathering sheep from the moors so that they can be moved onto each farmer's in-by (individually farmed grazing areas adjacent to the moorland) for dipping, breeding, lambing, etc. and for sharing out other management duties. However, on many moors these meetings no longer take place and these decisions are made on a more informal basis.

In the Peak District and Nidderdale grouse moor owners are the most widespread owners of moorland. Land ownership gives the fullest bundle of rights from access to alienation. However, other people such as the general public, water companies, tenant farmers and statutory bodies also have property rights which apply to moorland in private ownership. 
Table 2: property rights (vertical axis) associated with different stakeholders (horizontal axis) in uplands

\begin{tabular}{|c|c|c|c|c|c|c|c|}
\hline & $\begin{array}{l}\text { Recreational } \\
\text { groups/ } \\
\text { tourism* }\end{array}$ & $\begin{array}{l}\text { Statutory } \\
\text { bodies }\end{array}$ & Conservation & $\begin{array}{l}\text { Water } \\
\text { companies }\end{array}$ & Forestry & Agriculture & $\begin{array}{l}\text { Grouse moor } \\
\text { owners }\end{array}$ \\
\hline Access & $\begin{array}{l}\text { The CROW Act } \\
2000 \text { allows } \\
\text { open access } \\
\text { on foot to } \\
\text { mountains, } \\
\text { moorland, } \\
\text { downland, and } \\
\text { heathland and } \\
\text { to common } \\
\text { land in } \\
\text { England, in } \\
\text { Scotland } \\
\text { access is } \\
\text { granted by the } \\
\text { Land Reform } \\
\text { (Scotland) Act }\end{array}$ & $\begin{array}{l}\text { Access for } \\
\text { monitoring } \\
\text { adherence to } \\
\text { legislation }\end{array}$ & $\begin{array}{l}\text { Land ownership } \\
\text { by conservation } \\
\text { bodies (e.g. } \\
\text { Wildlife Trusts) } \\
\text { gives access to } \\
\text { exercise other } \\
\text { rights. Access } \\
\text { also granted to } \\
\text { the general } \\
\text { public }\end{array}$ & $\begin{array}{l}\text { Access to land } \\
\text { owned by the } \\
\text { water } \\
\text { company; } \\
\text { other access } \\
\text { for } \\
\text { maintenance } \\
\text { of pipelines on } \\
\text { private land }\end{array}$ & $\begin{array}{l}\text { Land } \\
\text { ownership } \\
\text { gives access } \\
\text { to exercise } \\
\text { other rights. } \\
\text { On state } \\
\text { owned land } \\
\text { managed by } \\
\text { Forestry } \\
\text { Commission } \\
\text { (FC) access by } \\
\text { the public is } \\
\text { allowed on a } \\
\text { permissive } \\
\text { basis }\end{array}$ & $\begin{array}{l}\text { Ownership, } \\
\text { tenancy } \\
\text { arrangements or } \\
\text { being a } \\
\text { gateholder gives } \\
\text { farmers access to } \\
\text { specific areas for } \\
\text { withdrawal or } \\
\text { management }\end{array}$ & $\begin{array}{l}\text { Land ownership } \\
\text { gives access to } \\
\text { exercise other } \\
\text { rights }\end{array}$ \\
\hline Withdrawal & $\mathrm{NO}$ & $\mathrm{NO}$ & $\begin{array}{l}\text { Have rights of } \\
\text { withdrawal on } \\
\text { owned land, } \\
\text { used specifically } \\
\text { for conservation } \\
\text { purposes; no } \\
\text { withdrawal } \\
\text { rights elsewhere }\end{array}$ & $\begin{array}{l}\text { Water } \\
\text { companies } \\
\text { have rights to } \\
\text { withdraw water } \\
\text { from upland } \\
\text { catchments }\end{array}$ & $\begin{array}{l}\text { Private land } \\
\text { owners have } \\
\text { rights of } \\
\text { withdrawal of } \\
\text { forest } \\
\text { products. FC } \\
\text { are able to } \\
\text { harvest forest } \\
\text { products on } \\
\text { land owned by } \\
\text { the state }\end{array}$ & $\begin{array}{l}\text { Ownership, } \\
\text { tenancy } \\
\text { arrangements or } \\
\text { being a } \\
\text { gateholder gives } \\
\text { farmers rights to } \\
\text { graze moorlands } \\
\text { but rights are } \\
\text { mediated by } \\
\text { tenancies and } \\
\text { regulation by } \\
\text { statutory bodies }\end{array}$ & $\begin{array}{l}\text { Ownership of a } \\
\text { grouse moor } \\
\text { allows game to } \\
\text { be shot and } \\
\text { through } \\
\text { tenancies } \\
\text { owners can } \\
\text { control } \\
\text { withdrawal by } \\
\text { farmers. }\end{array}$ \\
\hline Management & NO & $\begin{array}{l}\text { Through } \\
\text { moorland } \\
\text { management } \\
\text { plans; SSSI } \\
\text { designation; } \\
\text { farming } \\
\text { regulation; } \\
\text { conservation }\end{array}$ & $\begin{array}{l}\text { Where land is } \\
\text { owned they } \\
\text { have } \\
\text { management } \\
\text { rights, otherwise } \\
\text { they have no } \\
\text { management } \\
\text { rights elsewhere }\end{array}$ & $\begin{array}{l}\text { Through } \\
\text { tenancy } \\
\text { agreements on } \\
\text { owned land; } \\
\text { can block } \\
\text { some } \\
\text { pesticide/ } \\
\text { herbicide use }\end{array}$ & $\begin{array}{l}\text { Private owners } \\
\text { have } \\
\text { management } \\
\text { rights. FC } \\
\text { have } \\
\text { management } \\
\text { rights on } \\
\text { forested land }\end{array}$ & $\begin{array}{l}\text { Management of } \\
\text { sheep numbers, } \\
\text { movements and } \\
\text { breeds through } \\
\text { tenancy or } \\
\text { gateholdings. } \\
\text { Wider } \\
\text { management }\end{array}$ & $\begin{array}{l}\text { Vegetation } \\
\text { management } \\
\text { and control of } \\
\text { grazing through } \\
\text { tenancy } \\
\text { arrangements. } \\
\text { Management } \\
\text { mediated by }\end{array}$ \\
\hline
\end{tabular}




\begin{tabular}{|c|c|c|c|c|c|c|c|}
\hline & & legislation & & $\begin{array}{l}\text { on land in } \\
\text { catchments; } \\
\text { can lobby } \\
\text { government on } \\
\text { regulations } \\
\text { regarding } \\
\text { water quality }\end{array}$ & $\begin{array}{l}\text { owned by the } \\
\text { state. FC also } \\
\text { offers grants } \\
\text { and incentives } \\
\text { for private } \\
\text { woodland } \\
\text { management } \\
\text { and new } \\
\text { woodland } \\
\text { planting but } \\
\text { both are } \\
\text { voluntary } \\
\text { schemes }\end{array}$ & $\begin{array}{l}\text { rights when land } \\
\text { is owned. } \\
\text { Management also } \\
\text { mediated by } \\
\text { regulation by } \\
\text { statutory bodies }\end{array}$ & $\begin{array}{l}\text { regulation by } \\
\text { statutory bodies }\end{array}$ \\
\hline Exclusion & NO & $\begin{array}{l}\text { Decisions on } \\
\text { rights of } \\
\text { access } \\
\text { codified } \\
\text { through the } \\
\text { CROW Act } \\
\text { and the Land } \\
\text { Reform } \\
\text { (Scotland) Act }\end{array}$ & $\begin{array}{l}\text { Can control who } \\
\text { can withdraw } \\
\text { some on own } \\
\text { land but cannot } \\
\text { prevent access } \\
\text { on owned } \\
\text { moorland }\end{array}$ & $\begin{array}{l}\text { Exclusion } \\
\text { rights over } \\
\text { water } \\
\text { resources; } \\
\text { other rights } \\
\text { only on owned } \\
\text { land but } \\
\text { cannot prevent } \\
\text { access on } \\
\text { owned } \\
\text { moorland }\end{array}$ & $\begin{array}{l}\text { Private forestry } \\
\text { has rights of } \\
\text { exclusion. FC } \\
\text { can prevent } \\
\text { access to state } \\
\text { forestry in } \\
\text { cases where } \\
\text { management } \\
\text { precludes it. }\end{array}$ & $\begin{array}{l}\text { Shepherding and } \\
\text { monitoring can } \\
\text { prevent other } \\
\text { farmers grazing } \\
\text { on their areas. } \\
\text { Cannot prevent } \\
\text { access on } \\
\text { owned/tenanted } \\
\text { moorland }\end{array}$ & $\begin{array}{l}\text { Can control who } \\
\text { can withdraw } \\
\text { some resource } \\
\text { units but cannot } \\
\text { prevent access } \\
\text { on owned } \\
\text { moorland }\end{array}$ \\
\hline Alienation & NO & $\mathrm{NO}$ & $\begin{array}{l}\text { Sale of land } \\
\text { owned by NGOs } \\
\text { regulated by } \\
\text { charitable status }\end{array}$ & $\begin{array}{l}\text { Can sell water } \\
\text { withdrawal, } \\
\text { management } \\
\text { and exclusion } \\
\text { rights and land } \\
\text { holdings }\end{array}$ & $\begin{array}{l}\text { Private forestry } \\
\text { can sell } \\
\text { property to } \\
\text { others. FC } \\
\text { cannot sell } \\
\text { land owned by } \\
\text { the state } \\
\end{array}$ & $\begin{array}{l}\text { Alienation rights } \\
\text { on owned land. } \\
\text { Some tenancies } \\
\text { are hereditary but } \\
\text { farmers cannot } \\
\text { sell tenancies }\end{array}$ & $\begin{array}{l}\text { Can sell } \\
\text { property on to } \\
\text { others }\end{array}$ \\
\hline
\end{tabular}

* Two stakeholder categories have been combined in this column because their rights are the same. 


\section{Role of property rights in upland management}

There are two potential sources of conflict over resource management in uplands. The first is created by the perceived legitimacy of particular rights holders to have those rights and to exercise them. It is certainly true that many land owners and tenant farmers who have a long family history in upland areas feel that many of their rights have been unfairly removed or reduced by changing government policy. It seems that this conflict is the result of different understandings of property, that of exclusive dominion versus ownership as a bundle of rights (Hurley et al. 2002). Most land owners are likely to view ownership as giving them exclusive rights and the ability to make decisions over land management without interference. However, other stakeholders are likely to view property as a bundle of rights which can be distributed among different stakeholders and reflect the fact that there are multiple values attached to land (Ibid). The distribution of rights identified in this study suggests that the bundle of rights model operates in UK uplands. However, land owners still resist attempts to reduce or remove rights which they feel should rest with them and view other rights holders as having less legitimacy.

The second potential source of conflict is the fact that different property rights holders have different objectives for upland management. While grouse moor owners, private forestry and farmers manage uplands to maximise production this can bring them into conflict with other rights holders who want to manage uplands to maximise for water quality, carbon or conservation. It is argued that land management for production can lead to water discolouration, water acidification, carbon loss and reduced biodiversity although the evidence is not clear cut (Helliwell et al. 2001; Worral et al. 2006; Holden et al. 2007; Reed et al. In press). This suggests that it may not possible to manage uplands to maximise for all the ecosystem services. The conflict then lays in which of the rights holders is able to take precedence over the others in exercising their rights over land management.

The current management regimes are not able to influence land management decisions for the full range of ecosystem services. In part this is due to the uncertainty in the impact of different land management practices on some ecosystem services. Until these impacts are clearer it is difficult to assign the correct rights to each stakeholder so that they have enough influence over land management for their particular objectives. At the same time there are few arenas that bring rights holders together in order to make management decisions collectively. Collective choice arenas are important so that all rights holders can take part in management decisions (Ostrom 1990). Land owners are required to develop management plans for moorlands in conjunction with Natural England but other stakeholders such as water companies or recreation groups are rarely involved in that process. The assumption is that the statutory body will assure that the rights of other stakeholders are not infringed by the plans that they draw up. However, Natural England's priority is conservation and so the management plans will not necessarily reflect the objectives of other stakeholders except where those objectives coincide with or benefit from conservation. As a result, it is not the distribution of rights between different rights holders that acts as a barrier to sustainable 
management of uplands rather it is the lack of coordinated ways in which those rights can be exercised.

\section{Future policy for uplands}

There are two possible alternatives for future policy for upland management. One is to optimise for the range of ecosystem services across all the uplands rather than maximising for a particular ecosystem service such as agricultural production or water quality (Quinn et al. 2008). This would require trade-offs to be made by the different rights holders. For example, landowners could be required to forgo a certain amount of production while conservation organisations and water companies would have to except a less than maximum outcome in order to improve biodiversity conservation or water quality from current levels. This approach reflects current agricultural policy which subsidises farmers through agri-environmental schemes to improve biodiversity on agricultural land. Such schemes could be expanded to incorporate water quality or carbon storage. There are opportunities under the Kyoto Protocol for a voluntary carbon offset market to provide additional income for farmers to change their management practices to increase carbon stored in soils (Worral et al. 2003). Water companies could enter into private agreements with landowners to improve water quality, the cost of which could be off-set against the cost of building new water treatment works. This option would not require a substantial change in the current distribution of property rights, particularly if it was introduced on a voluntary basis but would require improved arenas for negotiation between different rights holders.

The second alternative is to zone the uplands so as to maximise for different ecosystem services in different areas (Quinn et al. 2008). For example, the uplands in Northern England could be prioritised for water quality given their importance as water catchments. All management for these uplands would focus on maximising water quality regardless of the impact on other ecosystem services. Other upland areas could then prioritise other ecosystem services such as conservation or agricultural production depending on their location. Implementing such a policy would require a substantial change to legislation to either pay land owners and managers to produce the required ecosystem services or to remove and redistribute the rights of the current property rights holders.

\section{Conclusions}

The current property regimes in UK uplands do lead to conflict. This is due to the perceived legitimacy of different rights holders to hold and exercise those rights and because the different rights holders have different objectives for upland management. The current regime is unable to influence all decisions about land management for different ecosystem services because the relationship between management and some ecosystem services is unclear and because arenas for bringing all rights holders together to make management decisions are rare. 
Possible options for policy makers are to optimise for a range of ecosystem services across the uplands by expanding current policy and providing arenas to negotiate tradeoffs or to zone the uplands so that different ecosystem services can be maximised in different areas. The need for uplands to produce a range of ecosystem services, some public goods and some private, means that there are some difficult choices ahead. Complex regimes where rights are distributed across a range of stakeholders with different and sometimes competing objectives does not necessarily preclude sustainable management but if these regimes are to function then arrangements need to be in place for rights holders to come together to make decisions.

\section{Acknowledgements}

Authors are funded through the Rural Economy and Land Use (RELU) programme, cosponsored by DEFRA and SEERAD (project RES-224-25-0088).

\section{References}

Bevan B. (In press) Moors from the past. In: Drivers of Change in Upland Environments (eds. Bonn A, Hubacek K, Stewart J \& Allot T). Routledge, Oxford

Corbin J. \& Strauss A.L. (1990) Grounded theory research: procedures, canons and evaluative criteria. Qualitative Sociology, 13, 3-21

Curry N. (In press) Leisure in the landscape: rural incomes and public benefits. In: Drivers of Change in Upland Environments (eds. Bonn A, Hubacek K, Stewart J \& Allot $\mathrm{T}$ ). Routledge, Oxford

Dougill A.D., Fraser E.D.G., Holden J., Hubacek K., Prell C., Reed M., Stagl S. \& Stringer L.C. (2006) Learning from doing participatory rural research: lessons from the Peak District National Park. Journal of Agricultural Economics, 57, 259275

Forestry Commission Scotland (2008) Galloway Forest Park, http://forestry.gov.uk/gallowayforestpark.

Gardner S.M., Waterhouse T. \& Critchley N.R. (In press) Moorland management with livestock: the effect of policy change on upland grazing, vegetation and farm economics. In: Drivers of Change in Upland Environments (eds. Bonn A, Hubacek K, Stewart J \& Allot T). Routledge, Oxford

Heal W. (2003) Introduction, context and seminar conclusions. In: Managing upland catchments: priorities for water and habitat conservation. Joint Nature Conservation Committee, Durham

Helliwell R.C., Ferrier R.C., Johnston L., Goodwin J. \& Doughty R. (2001) Land use influences on acidification and recovery of freshwaters in Galloway, south-west Scotland. Hydrology and Earth System Sciences, 5, 451-458

Hodge I. (2001) Beyond agri-environmental policy: towards an alternative model of rural environmental governance. Land Use Policy, 18, 99-111

Holden J., Shotbolt L., Bonn A., Burt T.P., Chapman P.J., Dougill A.D., Fraser E.D.G., Hubacek K., Irvine B., Kirkby M.J., Reed M., Prell C., Stagl S., Stringer L.C., Turner A. \& Worrall F. (2007) Environmental change in moorland landscapes. Earth Science Reviews, 82, 75-100 
Hurley J.M., Ginger C. \& Capen D.E. (2002) Property concepts, ecological thought, and ecosystem management: A case of conservation policy making in Vermont. Society \& Natural Resources, 15, 295-312

Lane S.N. (2003) The environment - visions, values and innovation. In: Proceedings of Chartered Institution of Water Environmental Management National Conference, Harrogate

Matthews K.B., Wright I.A., Buchan K., Davies D.A. \& Schwarz G. (2006) Assessing the options for upland livestock systems under CAP reform: developing and applying a livestock systems model within whole-farm systems analysis. Agricultural Systems, 90, 32-61

Moors for the Future (2007) Peak District Moorland: Carbon Flux [online]. Research Note 12, Available at: www.moorsforthefuture.org.uk/mftf/downloads/publications/

National Association for AONBs (2003) AONBs in more detail, http://www.aonb.org.uk.

Nidderdale AONB (2008) Welcome to Nidderdale, http://www.nidderdaleaonb.org.uk.

Office for National Statistics (2003) Census 2001: CD supplement to the National report for England and Wales and key statistics for local authorities in England and Wales. Office for National Statistics, London.

Ostrom E. (1990) Governing the Commons: The evolution of institutions for collective action. Cambridge University Press, Cambridge.

Peak District National Park (2004) State of the Park Report (update), http://www.peakdistrict.org.

Prell C., Hubacek K. \& Reed M. (In press) Stakeholder analysis and social network analysis in natural resource management. Society \& Natural Resources

Quinn C.H., Hubacek K. \& Reed M. (2008) Implications for rural livelihoods. In: FIRES seminar 1: The Role of Managed Fire in Ecosystem Services of UK Moorlands and Heathlands, Edinburgh

Reed M., Arblaster K., Bullock C., Burton R., Fraser E.D.G., Holden J., Hubacek K., Mitchley J., Morris J., Potter C., Quinn C.H. \& Swales V. (In press) Using scenarios to explore UK upland futures. Futures

Schlager E. \& Ostrom E. (1992) Property-Rights Regimes and Natural-Resources - a Conceptual Analysis. Land Economics, 68, 249-262

Simmons I.G. (2004) The moorlands of England and Wales: an environmental history $8000 B C$ to $A D$ 2000. Edinburgh University Press, Edinburgh.

Sotherton N.W., May R., Ewald J., Fletcher K. \& Newborn D. (In press) Managing uplands for game and sporting interests - an industry perspective. In: Drivers of Change in Upland Environments (eds. Bonn A, Hubacek K, Stewart J \& Allot T). Routledge, Oxford

Suckall N., Fraser E.D.G., Cooper T. \& Quinn C.H. (In Press) The challenge of matching environmental conservation and visitors' cultural identity in the Peak District National Park, United Kingdom. Journal of Environmental Management

Tallis J.H., Meede R. \& Hulme P.D. (1998) Introduction. In: Blanket mire degradation, proceedings. (eds. Tallis JH, Meede R \& Hulme PD), pp. 1-2. British Ecological Society, Manchester

Watson A. \& Miller G.R. (1976) Grouse Management. Game and Wildlife Conservation Trust, Fordingbridge, Hampshire. 
Worral F., Armstrong A. \& Adamson J.K. (2006) The effects of burning and sheep grazing on water table depth and soil water quality in an upland peat. Journal of Hydrology, 339, 1-14

Worral F., Reed M.S., Warburton J. \& Burt T. (2003) Caron budget for a British upland peat catchment. Science of the Total Environment, 312, 133-146 